\title{
Oligomerization and characteristics of phosphoenolpyruvate carboxylase in Synechococcus PCC 7002
}

\begin{abstract}
Claudia Durall ${ }^{1}$, Sandesh Kanchugal P. ${ }^{2}$, Maria Selmer ${ }^{2}$ \& Peter Lindblad ${ }^{1 *}$
Phosphoenolpyruvate carboxylase (PEPc) is an essential enzyme in plants. A photosynthetic form is present both as dimer and tetramer in C4 and CAM metabolism. Additionally, non-photosynthetic PEPcs are also present. The single, non-photosynthetic PEPc of the unicellular cyanobacterium Synechococcus PCC 7002 (Synechococcus), involved in the TCA cycle, was examined. Using size exclusion chromatography (SEC) and small angle X-ray scattering (SAXS), we observed that PEPc in Synechococcus exists as both a dimer and a tetramer. This is the first demonstration of two different oligomerization states of a non-photosynthetic PEPc. High concentration of $\mathrm{Mg}^{2+}$, the substrate PEP and a combination of low concentration of $\mathrm{Mg}^{2+}$ and $\mathrm{HCO}_{3}{ }^{-}$induced the tetramer form of the carboxylase. Using SEC-SAXS analysis, we showed that the oligomerization state of the carboxylase is concentration dependent and that, among the available crystal structures of PEPc, the scattering profile of PEPc of Synechococcus agrees best with the structure of PEPc from Escherichia coli. In addition, the kinetics of the tetramer purified in presence of $\mathrm{Mg}^{2+}$ using SEC, and of the mixed population purified in presence of $\mathrm{Mg}^{2+}$ using a Strep-tagged column were examined. Moreover, the enzyme showed interesting allosteric regulation, being activated by succinate and inhibited by glutamine, and not affected by either malate, 2-oxoglutarate, aspartic acid or citric acid.
\end{abstract}

Phosphoenolpyruvate carboxylase (PEPc) is a carbon dioxide fixing enzyme that in an irreversible manner and in the presence of $\mathrm{Mg}^{2+}$, converts phosphoenolpyruvate and bicarbonate into oxaloacetate and inorganic phosphorus. It is present in bacteria (including cyanobacteria), algae, fungi and plants ${ }^{1}$. PEPc has been demonstrated to be involved in atmospheric $\mathrm{CO}_{2}$ fixation and storing carbon in cell vacuoles, play an anapleurotic role, supply energy for symbiotic bacteria, produce energy, abiotic stress acclimation, seed formation, and in the development and cell expansion ${ }^{2}$.

Plants have at least two PEPc enzymes, a plant-type PEPc and a bacterial-type PEPc. Plant-type PEPcs are categorized to be either photosynthetic (C4 or Crassulacean acid metabolism, CAM) or non-photosynthetic enzymes (C3 metabolism). Plant-type PEPcs are 105-110 kDa polypeptides with a conserved N-terminus and form a homotetrameric form, class 1 . Plant bacterial-type PEPcs have larger polypeptides (116-118kDa) with a non-conserved $\mathrm{N}$-terminus, class 2 . Class 2 polypeptides may associate with class 1 ones resulting in a hetero-octameric form ${ }^{2}$. In algae, PEPc exists in at least two isoforms; one being a homotetramer while the other(s) seems to consist of a carboxylase catalytic unit together with some unrelated polypeptides, whose proposed interactions may regulate the enzyme in $v_{i v o^{3-6}}$.

In cyanobacteria, only one isoform of PEPc has been identified so $\mathrm{far}^{7-9}$. The cyanobacterial PEPc is present as a single copy gene and it is essential for the cells ${ }^{10}$. High order cyanobacteria possess PEPc amino acid sequences more similar to PEPc in C4 type higher plants, while in low order cyanobacteria the PEPc amino acid sequences do not resemble neither the PEPcs of C3 nor C4 plants ${ }^{11}$. In general, the PEPc enzymes have a conserved C-terminus and conserved essential amino acids for catalysis but differ in their $\mathrm{N}$-terminus resulting in different regulations. For instance, plant PEPc enzymes have a conserved serine that can be phosphorylated thereby activating the enzyme $\mathrm{e}^{12-14}$.

In the plant $\mathrm{C} 3$ metabolism, Ribulose- 1,5-bisphosphate carboxylase/oxygenase ( $\mathrm{RuBis} \mathrm{CO})$ is the primary $\mathrm{CO}_{2}$ fixing enzyme ${ }^{15-17}$. In addition to fix $\mathrm{CO}_{2}$, RuBisCO can function as an oxygenase where $\mathrm{O}_{2}$ is fixed and further metabolized in the so called photorespiration, an essential metabolic process in which $\mathrm{CO}_{2}$ is released ${ }^{18}$.

${ }^{1}$ Microbial Chemistry, Department of Chemistry - Ångström, Uppsala University, P.O. Box 523, SE-751 20, Uppsala, Sweden. ${ }^{2}$ Department of Cell and Molecular Biology, BMC, Uppsala University, P.O. Box 596, SE-751 24, Uppsala, Sweden. *email: peter.lindblad@kemi.uu.se 

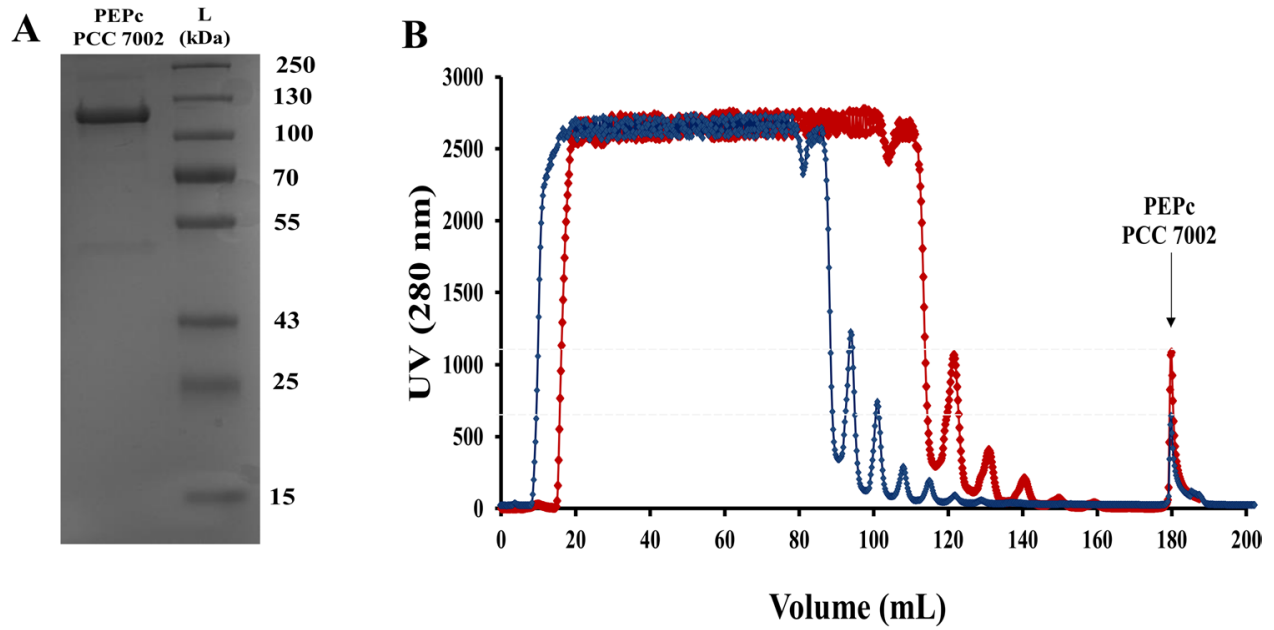

Figure 1. Purification of PEPc from the cyanobacterium Synechococcus PCC 7002. (A) Purified PEPc from the cyanobacterium Synechococcus PCC 7002. PEPc PCC 7002 corresponds to the purified PEPc with a tag attached to the $\mathrm{N}$-terminus. L corresponds to the ladder used in $\mathrm{kDa}$. (B) Chromatogram showing the purification of PEPc PCC 7002 using a Strep-Column and chromatography with TBS pH 8.0 (Blue) or TBS pH 8.0 and 25 mM $\mathrm{MgCl}_{2}$ (Red).

PEPc in C3 plants, bacteria and cyanobacteria, contributes to the tricarboxylic acid cycle (TCA) playing an anapleurotic role providing carbon skeletons to the nitrogen metabolism which, at least in cyanobacteria, may account up to $20 \%$ of the total carbon fixed ${ }^{8,10}$.

In $\mathrm{C} 4$ and CAM plants, with a more efficient $\mathrm{CO}_{2}$ fixation process in which RuBisCO avoids to use $\mathrm{O}_{2}$ as a substrate, photorespiration is more or less negligible. PEPc, the primary carbon fixation enzyme, is present in the mesophyll cells in the leaves where it fixes $\mathrm{CO}_{2}$ and uses phosphoenolpyruvate (PEP) to produce oxaloacetate that is converted into malate. Malate is transported to the sheath cells, where RuBisCO is located, and is converted to pyruvate and $\mathrm{CO}_{2}$. Evolved $\mathrm{CO}_{2}$ is fixed by the most abundant protein on earth, RuBiSCO. Pyruvate is finally transported to the mesophyll cells in order to restart the cycle ${ }^{19}$.

It is known that $\mathrm{C} 4$ plants fix carbon through PEPc and RuBisCO during conditions of light and $\mathrm{RuBisCO}$ needs significant amounts of NADPH and ATP produced by the light dependent photosynthetic reactions. By contrast, CAM plants close the stomata during the day in order to avoid evaporation of water and $\mathrm{CO}_{2}$ cannot be fixed by PEPc. In addition, malate is present in the cytoplasm of the cells and any free metal ions are complexed. These factors dissociate the carboxylase to a dimer, which is the inactive form. During darkness, the stomata are open, divalent cations are free, malate concentration is low and the oligomerization state of the enzyme is a tetramer which is the active form. As consequence, PEPc fixes $\mathrm{CO}_{2}$ and the plant stores malate in the vacuole until the light reactions of photosynthesis are active again and $\mathrm{RuBisCO}$ can fix the $\mathrm{CO}_{2}$ released from malate by the malic enzyme ${ }^{20}$.

Different studies have examined the activity and regulation of PEPc in selected cyanobacterial strains ${ }^{7-9}$. However, so far, there are no studies addressing the oligomerization states of PEPc in cyanobacteria and this an important factor to understand the regulation of this enzyme in vivo. Herein, we examine and characterize the single PEPc from the low order unicellular cyanobacterium Synechococcus PCC 7002. The faster growth of this organism compared to e.g. Synechocystis PCC $6803^{21}$ may indicate different kinetics of the $\mathrm{CO}_{2}$ fixing enzymes and despite being a marine strain has conserved amino acids residues characteristic of PEPc from freshwater strains ${ }^{14}$.

\section{Results}

Expression and purification of PEPc PCC 7002. PEPc PCC 7002 was cloned with a Strep-tag and expressed and harvested in Escherichia coli in order to be purified. After trying different conditions, the optimal IPTG concentration and temperature for expression of PEPc from Synechococcus PCC 7002 (Synechococcus) were $0.1 \mathrm{mM}$ IPTG and $25^{\circ} \mathrm{C}$, respectively. Interestingly, when the Strep tag was attached to the C-terminus of the PEPc from Synechococcus, the protein did not attach to the column and no enzyme could be purified (data not shown). However, changing the position of the Strep tag to the N-terminus of the carboxylase resulted in a successful purification of PEPc PCC 7002 with a size agreeing with the theoretical molecular weight of $115.4 \mathrm{kDa}$ (Fig. 1A). In addition, when the carboxylase was purified in the presence of $\mathrm{Mg}^{2+}$ (red line) the amount of purified protein increased 2-fold compared to in absence of the divalent cation (blue line) (Fig. 1B).

Oligomerization of PEPc PCC 7002. The purified PEPc PCC 7002 was analysed using size exclusion chromatography (SEC). Using the Superdex 200 column, a peak corresponding to a low molecular weight oligomer of PEPc PCC 7002 (D_PEPc PCC 7002) was present in all purification conditions examined (Dimer, Table 1). Additionally, another higher molecular weight oligomer (larger oligomer) peak (T_PEPc PCC 7002) was present under few conditions (Tetramer, Table 1). High concentration of $\mathrm{Mg}^{2+}\left(\mathrm{Mg} \_25\right.$, Table 1, Supplemenary Information Fig. S1) induced the larger oligomer but lower concentration of the divalent cation did not (Mg_10, 


\begin{tabular}{|c|c|c|c|c|c|}
\hline Buffer & Addition to the TBS buffer & Tetramer & Dimer & $\begin{array}{l}\text { Ratio } \\
\text { (Tetramer:Dimer) }\end{array}$ & $\begin{array}{l}\text { Supplementary } \\
\text { Fig. S1 }\end{array}$ \\
\hline TBS & - & - & + & $0: 1$ & A \\
\hline Mg_25 & $25 \mathrm{mM} \mathrm{MgCl}_{2}$ & + & + & $1.4: 1$ & B \\
\hline Mg_10 & $10 \mathrm{mM} \mathrm{MgCl}_{2}$ & - & + & $0: 1$ & C \\
\hline $\mathrm{HCO}_{3}^{-}$ & $5 \mathrm{mM} \mathrm{NaHCO}_{3}^{-}$ & - & + & $0: 1$ & $\mathrm{D}$ \\
\hline PEP & $5 \mathrm{mM}$ PEP & + & + & $1.1: 1$ & $\mathrm{E}$ \\
\hline $\mathrm{Mg} \_10+\mathrm{HCO}_{3}^{-}$ & $10 \mathrm{mM} \mathrm{MgCl}_{2}$ and $5 \mathrm{mM} \mathrm{NaHCO}_{3}^{-}$ & + & + & $0.8: 1$ & F \\
\hline Mg_10+PEP & $10 \mathrm{mM} \mathrm{MgCl}_{2}$ and $5 \mathrm{mM} \mathrm{PEP}$ & + & + & $1.3: 1$ & G \\
\hline $\mathrm{HCO}_{3}^{-}+\mathrm{PEP}$ & $5 \mathrm{mM} \mathrm{NaHCO}_{3}{ }^{-}$and $5 \mathrm{mM} \mathrm{PEP}$ & + & + & $0.8: 1$ & $\mathrm{H}$ \\
\hline $\mathrm{Mg} \_10+\mathrm{HCO}_{3}^{-}+\mathrm{PEP}$ & $10 \mathrm{mM} \mathrm{MgCl}_{2}, 5 \mathrm{mM} \mathrm{NaHCO}_{3}{ }^{-}$and $5 \mathrm{mM} \mathrm{PEP}$ & + & + & unknown & I \\
\hline
\end{tabular}

Table 1. Oligomerization forms of PEPc from Synechococcus PCC 7002 when eluted from the Superdex (SEC) using TBS buffer with different additives.

Table 1). When $\mathrm{HCO}_{3}{ }^{-}$was used, the larger oligomer was not present $\left(\mathrm{HCO}_{3}{ }^{-}\right.$, Table 1$)$. Interestingly, when $\mathrm{HCO}_{3}{ }^{-}$and the lower concentration of $\mathrm{Mg}^{2+}$ were combined, the larger oligomer was eluted $\left(\mathrm{Mg}_{-} 10+\mathrm{HCO}_{3}{ }^{-}\right.$, Table 1). Presence of PEP induced the larger oligomer when used alone, or combined with either $\mathrm{HCO}_{3}{ }^{-}$or low concentration of $\mathrm{Mg}^{2+}\left(\mathrm{PEP}, \mathrm{HCO}_{3}{ }^{-}+\mathrm{PEP}\right.$ and $\mathrm{Mg} \_10+\mathrm{PEP}$, Table 1). When an in vitro reaction was performed ${ }^{22}$, both oligomers were eluted (PEP $+\mathrm{HCO}_{3}^{-}+\mathrm{Mg} \_10$, Table 1, Fig. 2).

Small angle X-ray scattering (SAXS). In order to further clarify and confirm which oligomeric states of PEPc from Synechococcus were present at different conditions, size-exclusion chromatography coupled to small-angle X-ray scattering (SEC-SAXS) was performed at beamline B21 at Diamond Light Source. At all tested conditions, three peaks could be observed, an initial shoulder (peak 1), a main peak (peak 2) and a smaller peak or shoulder at the end (peak 3) (Fig. 3A). Using the estimated radius of gyration $\left(R_{g}\right)$ for each data frame as a guide (Fig. 3B,C), scattering curves from each peak were analyzed separately to determine the size and shape of the different oligomers in the sample.

The radii of gyration and molecular weights derived using the different available methods (Fig. 3D, Table 2) show reasonable agreement with the minor peak 1 consisting of octamers (theoretical MW $924 \mathrm{kDa}$ ) or decamers (theoretical MW $1.15 \mathrm{MDa}$ ), the main peak 2 containing tetramers (theoretical MW $462 \mathrm{kDa}$ ) and peak 3 containing dimers (theoretical MW $231 \mathrm{kDa}$ ) (Table 2). The Kratky plots for peaks 1 and 2 shows the double bell-shape characteristic of multidomain proteins, while the corresponding plot for peak 3 shows a normal bell-shape indicating that the dimer is compact (Supplementary Information, Fig. S2). Based on the Kratky plots (Supplementary Information, Fig. S2), all oligomers are well folded.

Comparison of the SEC-SAXS signal plots for PEPc at 6.5 and $0.87 \mathrm{mg} \cdot \mathrm{ml}^{-1}$ in TBS (Fig. 3A) shows that the proportion of dimer increases at lower concentration, consistent with a concentration-dependent equilibrium between dimer and tetramer. The signal plot in presence of $25 \mathrm{mM} \mathrm{Mg}^{2+}$ shows a smaller fraction of dimer than in absence of $\mathrm{Mg}^{2+}$, suggesting that the tetramer is stabilized by $\mathrm{Mg}^{2+}$.

There are available crystal structures of PEPc from bacteria (E. coli) and plants (maize, Flaveria trinervia and F. pringlei), but there is at present no structure of a PEPc from any cyanobacterium. Aiming to find out which of the available crystal structures were most similar to PEPc PCC 7002, the experimental scattering curves were compared to calculated scattering curves of biological dimers and tetramers generated from the available PDB entries (Supplementary Information, Table S1). The tetramer observed in solution is most similar to the E. coli PEPc tetramers (Fig. 3E,F, PDB entries 1FIY, 1JQN, 1QB4). Similarly, the dimer observed in solution is most similar to the E. coli PEPc dimers (Fig. 3G, PDB entries 1FIY, 1JQN, 1QB4). The dimer data shows a better fit with calculated scattering curves (lowest $\chi^{2} 1.47$ ) than the tetramer data (lowest $\chi^{2} 5.03$ ), suggesting that some changes compared to the crystallized tetramer are observed in solution. The crystal packing in the available structures does not suggest any obvious octamer or decamer, for which reason no fitting was attempted for peak 1 .

The SAXS experiments were also performed in batch mode in TBS buffer at different protein concentrations. The shape of the scattering curve changes with protein concentration (Fig. 4A), in agreement with a concentration-dependent equilibrium. Guinier analysis (Fig. 4B) and estimation of average molecular weight shows that the average oligomer size increases with concentration (Table 2) which can also be observed in the Kratky and P(r) plots (Fig. 4C,D). However, even at the lowest tested concentration, $0.2 \mathrm{mg} \cdot \mathrm{ml}^{-1}$, the estimated $\mathrm{R}_{\mathrm{g}}$ and molecular weight are higher than for the dimer in peak 3 of the SEC-SAXS analysis, showing that PEPc never completely dissociates to dimers under these experimental conditions. Importantly, these measurements would be skewed towards larger sizes if any fraction of aggregates were present in the samples. At the lowest concentrations, the batch data is relatively noisy and may show signs of aggregation (Fig. 4A), but there is no sign of aggregation at the higher concentrations or in the SEC-SAXS data (Fig. 3A).

Kinetic characterization of PEPc Synechococcus PCC 7002. Purified PEPc PCC 7002 and T_PEPc PCC 7002 were characterized. The optimal pH of PEPc PCC 7002 was determined to be 7.5 for the purified protein with $\mathrm{Mg}^{2+}$ and 8.0 for T_PEPc PCC 7002, even though no significant differences were observed between $\mathrm{pH} 7.5$ and 8.0 (Figs. 5A and $6 \mathrm{~A}$, respectively). The optimal temperature was $35^{\circ} \mathrm{C}$ (Figs. $5 \mathrm{~B}$ and $6 \mathrm{~B}$ ). The enzyme was found to be unstable with time, but it clearly obeyed Michaelis-Menten kinetics (Figs. 5, 6C,D). Calculated $\mathrm{V}_{\max }$ for the

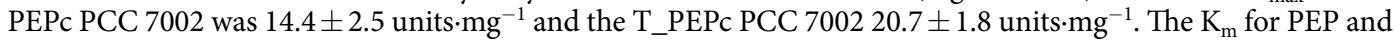




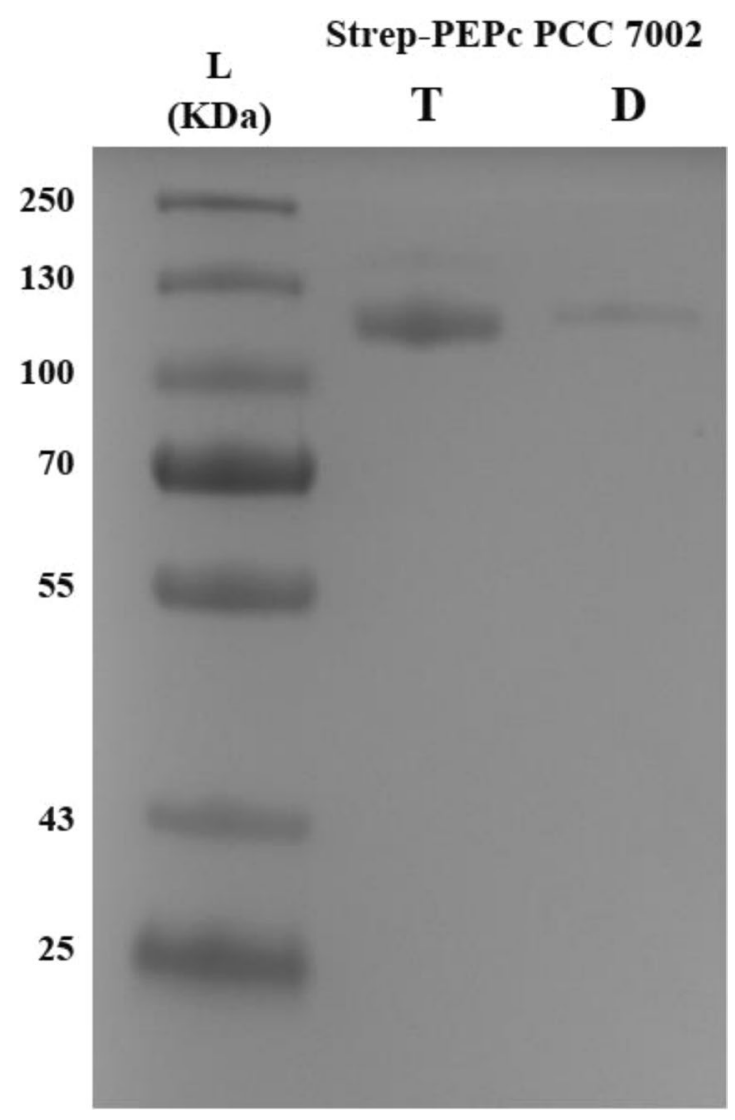

Figure 2. SDS-PAGE showing the eluted PEPc PCC 7002 after the PEPc reaction was performed (Mg_10+ $\mathrm{HCO}_{3}{ }^{-}+\mathrm{PEP}$, Table 1). D corresponds to the dimer form of PEPc PCC 7002, T corresponds to the tetramer form of PEPc PCC 7002, and L corresponds to the ladder used in $\mathrm{kDa}$.

$\mathrm{HCO}_{3}{ }^{-}$were 1.06 and $0.97 \mathrm{mM}$ for PEPc PCC 7002, and 0.77 and $0.24 \mathrm{mM}$ for T_PEPc PCC 7002, respectively. The D_PEPc PCC 7002 eluted using $\mathrm{Mg}^{2+}\left(\mathrm{Mg} 25\right.$, Table 1) showed a $\mathrm{V}_{\max }$ of $9.54 \pm 1.1$ units $\cdot \mathrm{mg}^{-1}$. Interestingly, neither malate, 2-oxoglutarate, glycine, aspartic acid or citric acid, potential inhibitors or activators of PEPc, did affect the $V_{\max }$ of the respective reaction (Fig. 7). However, addition of either succinic acid or glutamine resulted in significant differences in the observed $\mathrm{V}_{\max }(\mathrm{p}=0.043$ and $\mathrm{p}=0.037$, respectively) (Fig. 7). Thus, succinic acid and glutamine were shown to be an activator and an inhibitor, respectively, of T_PEPc PCC 7002.

\section{Discussion}

Phosphoenolpyruvate carboxylase (PEPc) of Synechococcus PCC 7002 was examined with the aim to examine oligomerization, structure and characteristics. The activity of PEPc in C4 and CAM plants have shown to be regulated through the oligomerization states during light and darkness ${ }^{23}$. In addition, some compounds inhibit or activate a specific oligomer form of the carboxylase ${ }^{23}$. However, this has not addressed for any cyanobacterial PEPc. In order to purify the PEPc PCC 7002 a strep tag was added to the N-terminus, in agreement with a previous study ${ }^{9}$. When initially added to the C-terminus, we were unable to observe any binding to the column and no protein could be purified. This is probably a consequence of the $\mathrm{C}$-terminus being buried inside the PEPc monomer, as is the case in homologous PEPc structures from bacteria and plants ${ }^{24,25}$. PEPc PCC 7002 purified under different conditions showed different oligomeric states. Using a high concentration of the cation $\mathrm{Mg}^{2+}$, a cofactor of PEPc, induced the tetramer form (Table 1, Fig. 3A), in agreement with earlier observations with PEPc from the plant Crassula argentea ${ }^{20}$. The tetrameric form may also have higher affinity to the Strep-column since four Strep tags are exposed compared to the dimeric form. It is also known that the tetramer is in all PEPcs stabilized by a salt bridge between arginine in position 503 and glutamic acid in position $498^{24}$ (PEPc from Synechococcus). When the protein is diluted, the fraction of dimer increases (Fig. 4, 25). This study showed two oligomerization states of the carboxylase based on the substrates and/or cofactor present. In addition, this is the first report showing two oligomeric states for a bacterial or cyanobacterial $\mathrm{PEPc}^{7-9,24}$.

The differences observed in the ratio of the two peaks in the two SEC columns used (Superdex and Shodex, Table 2 and Fig. 3A) can be attributed to the fact that the columns have different volumes (100 and $4.6 \mathrm{~mL}$, respectively), resulting in different degrees of dilution and different running times that may or may not allow the tetramer to reach equilibrium and dissociate into dimers during the run. In contrast to what has been shown for PEPc from $C$. argentea $^{20}$, a pure tetramer was never observed (Table 2 and Fig. $3 \mathrm{~A}$ ). In addition, we also observed a small fraction of a larger oligomer (octamer or possibly decamer) in all SEC-SAXS runs. This has never been observed before, and requires high-resolution SEC to be detected, but a hetero-octamer has been suggested for PEPc from class $2^{2}$. 
A

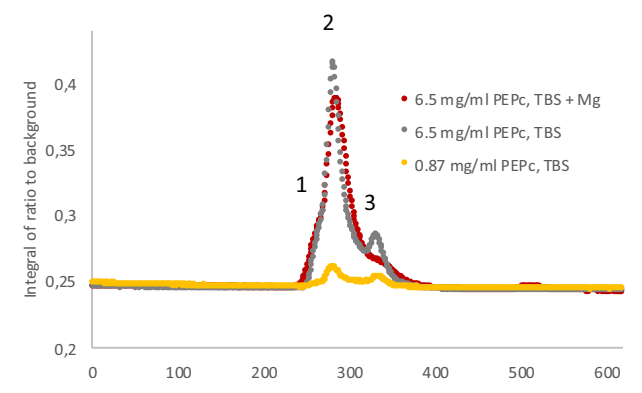

B

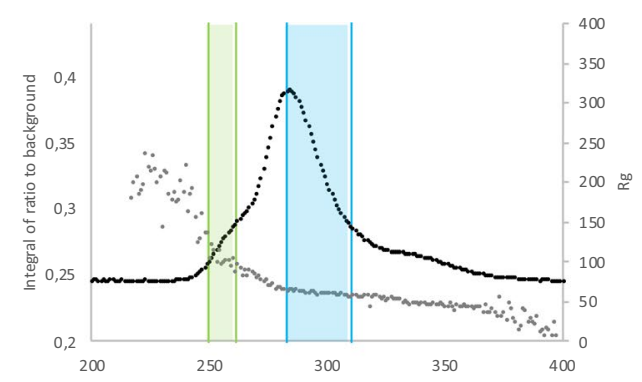

C

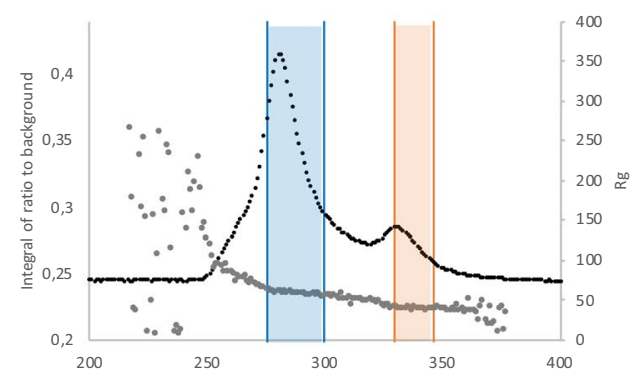

D

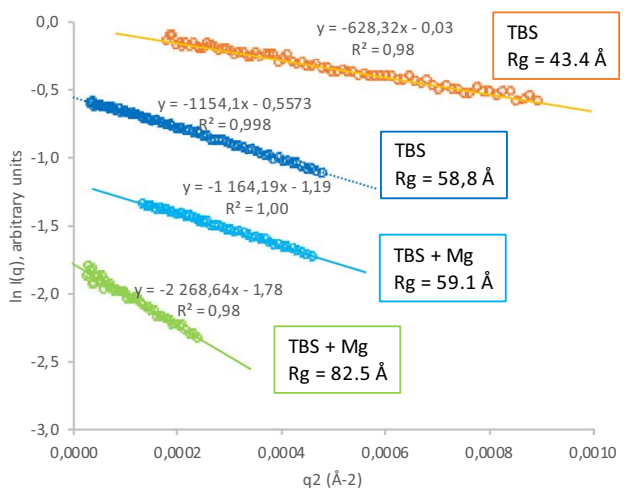

E

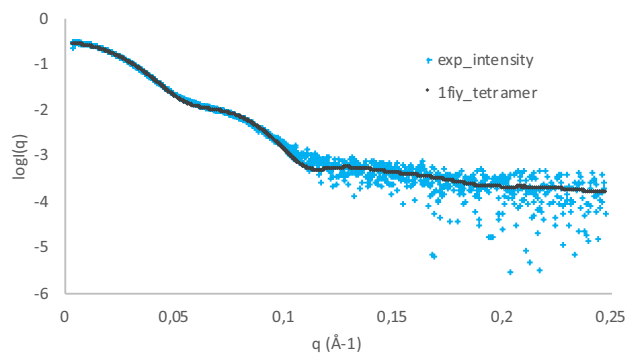

F

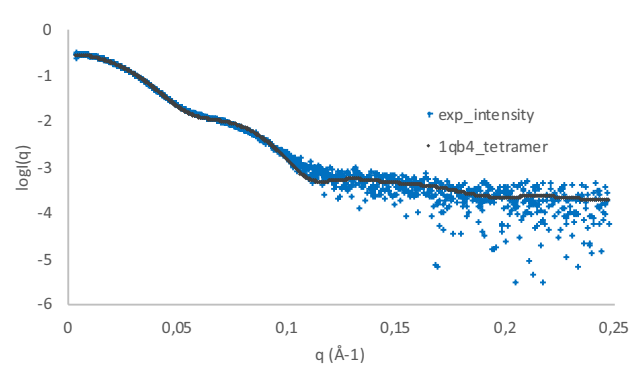

G

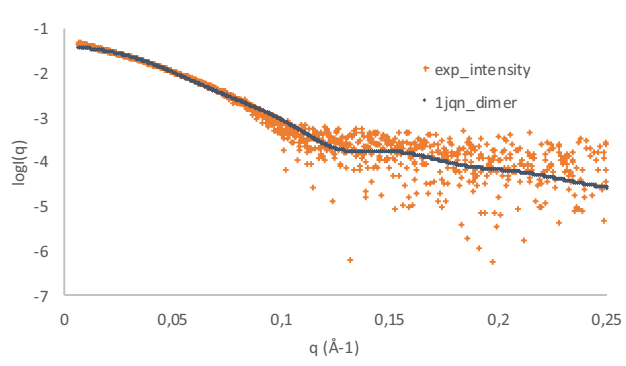

Figure 3. SEC-SAXS data. (A) Overlay of signal plots from SEC-SAXS of PEPc in TBS at two different concentrations (yellow, grey) and in TBS with $25 \mathrm{mM} \mathrm{MgCl}_{2}$. Peaks numbers are indicated. (B) Zoom in of signal plot for $6.5 \mathrm{mg} \cdot \mathrm{ml}^{-1}$ PEPc in TBS with $25 \mathrm{mM} \mathrm{MgCl}_{2}$ (red). Grey markers indicate the radius of gyration calculated from the individual scattering curves. Green bars indicate the data frames used for analysis of peak 1, cyan bars indicate the data frames used for analysis of peak 2. (C) Zoom in of signal plot for $6.5 \mathrm{mg} \cdot \mathrm{ml}^{-1} \mathrm{PEP} \mathrm{c}$ in TBS. Grey markers indicate the radius of gyration calculated from the individual scattering curves. Blue bars indicate the data frames used for analysis of peak 2, orange bars indicate the data frames used for analysis of peak 3. (D) Guinier plots used to derive $\mathrm{R}_{\mathrm{g}}$ for peak 1 and 2 in TBS $+\mathrm{Mg}$ (bottom) and for peak 2 and 3 in TBS (top). Colors as in B-C. (E) Experimental scattering curve for peak 2 in TBS + Mg overlaid with calculated scattering curves from a tetramer generated from PDB entry 1fiy. (F) Experimental scattering curve for peak 2 in TBS overlaid with calculated scattering curves from a tetramer generated from PDB entry 1qb4. (G) Experimental scattering curve for peak 2 in TBS overlaid with calculated scattering curves from a dimer generated from PDB entry ljqn. 


\begin{tabular}{|c|c|c|c|c|c|c|}
\hline Buffer & SEC-SAXS peak & \begin{tabular}{|l|}
$\mathrm{R}_{\mathrm{g}}(\AA)$ from \\
Primus $^{38}$
\end{tabular} & $\begin{array}{l}\text { Baysean inference MW }(\mathrm{kD}) \\
(\mathrm{MW} \text { probability }(\%))^{39}\end{array}$ & $\begin{array}{l}\text { MW }(\mathrm{kD}) \text { from } \\
\text { volume of correlation }\end{array}$ & $\begin{array}{l}\operatorname{Rg}(\AA) \text { from } \\
\text { SAXSMoW }\end{array}$ & \begin{tabular}{|l|} 
MW from \\
SAXSMoW
\end{tabular} \\
\hline $\mathrm{TBS}+\mathrm{Mg}$ & 1 & 82.5 & $873(92.3)$ & 1119 & 82.7 & 1133 \\
\hline $\mathrm{TBS}+\mathrm{Mg}$ & 2 & 59.1 & $479(79.0)$ & 510 & 59.8 & 524.5 \\
\hline TBS & 2 & 58.8 & $434(70.6)$ & 465 & 58.7 & 492.5 \\
\hline TBS & 3 & 43.4 & $170(81.3)$ & 157 & 43.0 & 174.6 \\
\hline Buffer & $\begin{array}{l}\text { Batch sample } \\
\text { conc. }(\mathrm{mg} / \mathrm{ml})\end{array}$ & $\mathbf{R}_{\mathrm{g}}(\AA)$ & $\begin{array}{l}\text { Baysean inference MW }(\mathrm{kD}) \\
(\mathrm{MW} \text { probability }(\%))^{*}\end{array}$ & $\begin{array}{l}\text { MW }(\mathrm{kD}) \text { from } \\
\text { volume of correlation }\end{array}$ & $\begin{array}{l}\operatorname{Rg}(\AA) \text { from } \\
\text { SAXSMoW }\end{array}$ & $\begin{array}{l}\text { MW from } \\
\text { SAXSMoW }\end{array}$ \\
\hline TBS & 0.2 & 57.5 & $243(76.3)$ & 252 & 56.8 & 318.2 \\
\hline TBS & 0.5 & 58.6 & $318(99.9)$ & 330 & 58.2 & 422.5 \\
\hline TBS & 1.0 & 62.3 & $392(40.2)$ & 430 & 62.0 & 486.9 \\
\hline TBS & 3.0 & 66.5 & $479(90.8)$ & 500 & 66.1 & 560.5 \\
\hline TBS & 4.3 & 68.3 & $479(95.0)$ & 523 & 68.2 & 589.5 \\
\hline
\end{tabular}

Table 2. Molecular parameters derived from analyses of SEC-SAXS (Fig. 3A-D) and from batch SAXS (Fig. 4) data.

A

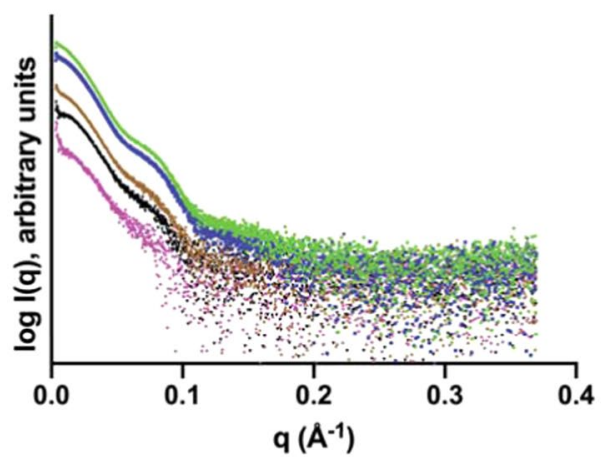

C

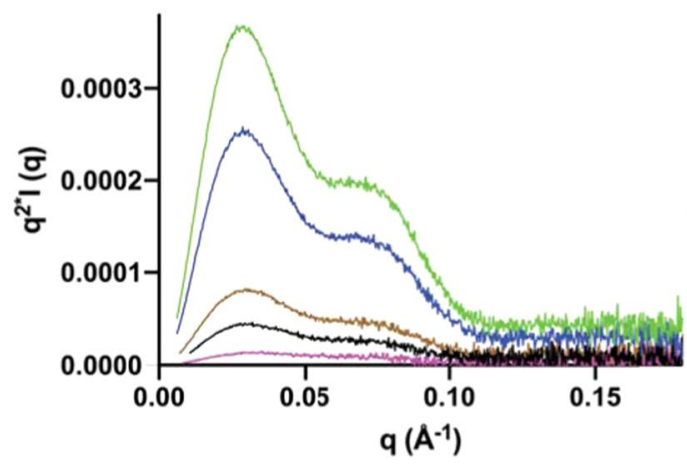

B

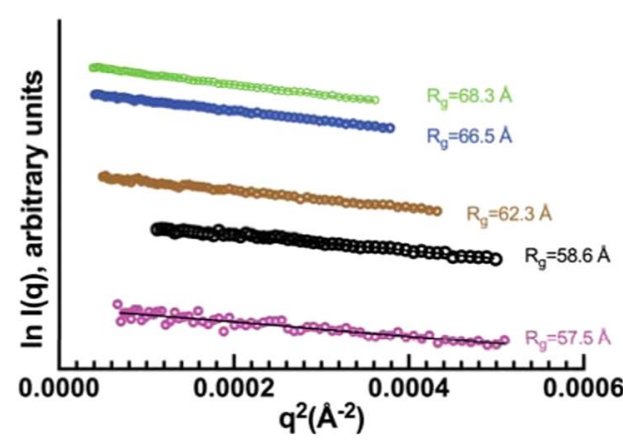

D

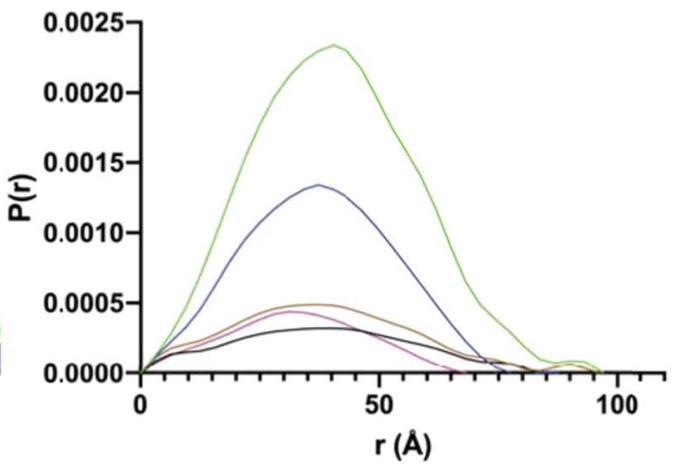

Figure 4. Batch SAXS data and analysis, all data have been plotted using offset for visualization purposes. (A) Experimental scattering curve of PEPc in TBS buffer at different concentrations (green $4.3 \mathrm{mg} \cdot \mathrm{ml}^{-1}$, blue $3 \mathrm{mg} \cdot \mathrm{ml}^{-1}$, brown $1 \mathrm{mg} \cdot \mathrm{ml}^{-1}$, black $0.5 \mathrm{mg} \cdot \mathrm{ml}^{-1}$ and magenta $0.2 \mathrm{mg} \cdot \mathrm{ml}^{-1}$ ). (B) Guinier plots used to derive $\mathrm{R}_{\mathrm{g}}$ values, colors are as in A. (C) Kratky plots, colors as in A. (D) Distance distribution P(r) plots. Derived $\mathrm{D}_{\max }$ values are 97, 97, 95, 83 and $80 \AA$.

Remarkably, we identified substrates of PEPc which induce the tetramer form (Table 1). The concentrations of the substrates used for the SEC are based on the concentrations used in our previous activity assays ${ }^{26}$.

It has been suggested that the biphasic behaviour of the enzyme when $\mathrm{Mg}^{2+}$ is present is due to a modification of a histidine residue ${ }^{26}$. Mukerji ${ }^{27}$ suggested that $\mathrm{Mg}^{2+}$ is an activator of PEPc. The fact that $\mathrm{Mg}^{2+}$ can be an activator may influence the oligomerization state of protein but the process is still unclear. In the present study, we observed that $\mathrm{Mg}^{2+}$ influences the oligomerization state of PEPc PCC 7002 (Table 1, Supplementary Information Figs. S1-B and 3). In addition, the low concentration of $\mathrm{Mg}^{2+}$ and $\mathrm{HCO}_{3}{ }^{-}$or $\mathrm{PEP}$ has shown to induce the tetramer oligomer of PEPc PCC 7002 and this a novel result (Table 1). However, it has been observed that the $\mathrm{Mg}^{2+}$-PEP complex may induce the tetramerization form in maize $\mathrm{PEPc}^{28}$. Our experiments show that the tetramer is the main oligomer after the reaction (Fig. 2), in agreement with other studies that have shown that the tetramer of PEPc is the active form of the protein ${ }^{20}$. 

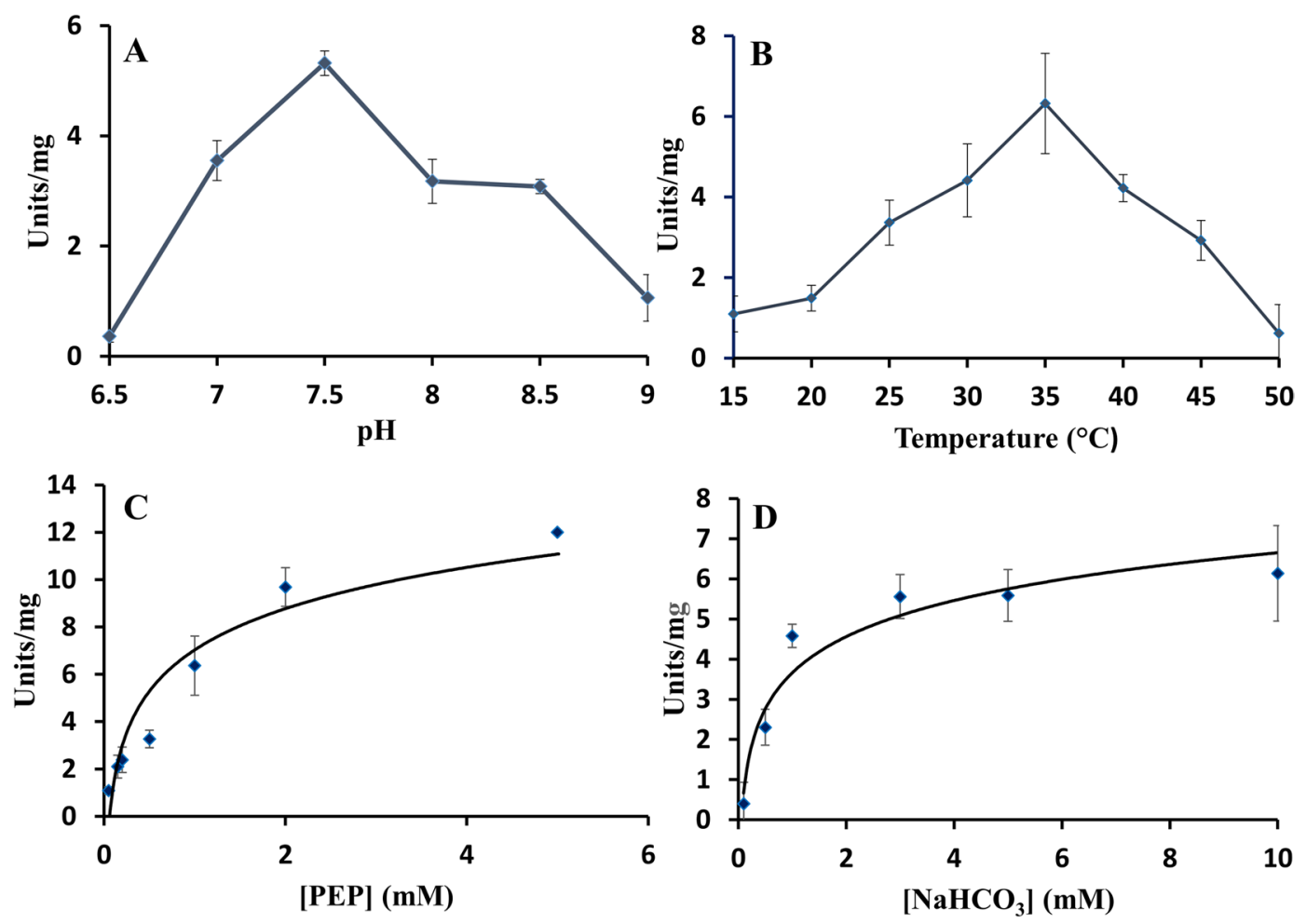

Figure 5. Specific activity of purified PEPc PCC 7002 (Table 1). (A) Specific activity of PEPc PCC 7002 with different $\mathrm{pHs}\left(23^{\circ} \mathrm{C}\right)$. (B) Specific activity of PEPc PCC 7002 with different temperatures ( $\left.\mathrm{pH} 7.5\right)$. (C) Specific activity of PEPc PCC 7002 dependent on the concentration of PEP $\left(\mathrm{pH} 7.5,35^{\circ} \mathrm{C}\right)$. (D) Specific activity of PEPc PCC 7002 dependent on the concentration of $\mathrm{NaHCO}_{3}\left(\mathrm{pH} 7.535^{\circ} \mathrm{C}\right)$. One unit is defined as $1 \mathrm{~mol}$ of $\mathrm{NAD}^{+}$ produced per minute.

Since the PEPc PCC 7002 showed different activity levels and the exact values dropped by half upon dilution (Fig. 5), the tetrameric form of PEPc PCC 7002 from purification in presence of $\mathrm{Mg}^{2+}$ was also characterized kinetically. The observed optimal pH of the PEPc PCC 7002 was in the same range as for all cyanobacterial PEPcs characterized so far (Table 3) and in full agreement with PEPc in Anabaena PCC 71209. The activation energy of T-PEPc PCC 7002 was estimated to be $59.3 \mathrm{KJ} / \mathrm{mol}$, more than double of PEPc from the cyanobacterium Coccochloris peniocystis ${ }^{8}$. According to our results, PEPc PCC 7002 showed Michaelis-Menten kinetics for both substrates, similar as for PEPc from C. peniocystis ${ }^{8}$ and contrary to PEPc from the green alga Selenastrum minutum ${ }^{3}$.

The PEPc PCC 7002 has the highest $\mathrm{Km}$ for $\mathrm{HCO}_{3}{ }^{-}$and PEP compared to other cyanobacterial PEPcs (Table 3) ${ }^{29}$. The fact that the T_PEPc PCC 7002 has a higher affinity for $\mathrm{HCO}_{3}{ }^{-}$compared to the PEPc PCC 7002 can be due to T_PEPc PCC 7002 may be mainly tetramers (active form) while PEPc PCC 7002 might be an equilibrium between tetramers and dimers. In addition, in agreement with Takeya et al. ${ }^{9}$ and Schylajanaciyar et al. ${ }^{11}$, it seems that strains belonging to Chroococcales have a lower Km for PEP than those in Nostocales, as PEPc from Anabaena PCC 7210 showed an even higher Km value for PEP than PEPc PCC 7002 (Table 3). However, we believe that in the cyanobacterial cells, PEP is not a limiting metabolite. In light, when photosynthesis is active and RuBisCO fixes $\mathrm{CO}_{2}{ }^{18}$, and in darkness, when glycolysis is active, the level is lower but there is still PEP in the cells ${ }^{30,31}$. It is relevant to note that cyanobacteria have active inorganic carbon transporters ${ }^{32}$ and that the amount of bicarbonate inside the cells is around $4 \mathrm{mM}$ during the day and lower during the night ${ }^{33}$ but PEPc is also active in darkness (35, unpublished) and as a consequence the carboxylase may not necessarily have high affinities for these substrates.

Malate is a well-known inhibitor of PEPc ${ }^{7,9,20,34}$. However, under the conditions examined, the T_PEPc PCC 7002 activity was not repressed by malate and this is in agreement with observations for PEPc from the cyanobacterium S. volcanus (at pH 7.5) ${ }^{7}$. In plants, the photosynthetic PEPc seems to be regulated by malate and other factors. Firstly, PEPc of C3 plants, Mesembrutanthermum crystallinun and Spinacia oleracea, from light and dark forms, are inhibited by malate ${ }^{34}$. Secondly, C4 PEPc from Zea mays showed higher sensitivity to malate in darkness, which is typical for C4 plants ${ }^{33}$. Thirdly, in the CAM plant Crassula malate inhibits PEPc in the dimeric form and it might be responsible to regulate the carboxylase activity during day and night cycles ${ }^{20,34}$. This study can conclude that malate is not an allosteric inhibitor of T_PEPc PCC 7002 when $\mathrm{Mg}^{2+}$ is present, but it might be an inhibitor when $\mathrm{Mg}^{2+}$ is absent or induce dissociation into dimers in absence of divalent ions. Interestingly, high order cyanobacteria seem to have a conserved serine residue characteristic for PEPc of C4 plants, an amino acid suggested to be involved in aspartate inhibition ${ }^{9,11}$. Conversely, PEPc of some low order cyanobacteria (e.g. Synechocystis PCC 6803 and Synechococcus PCC 7002) have a serine residue in the corresponding position (S817 

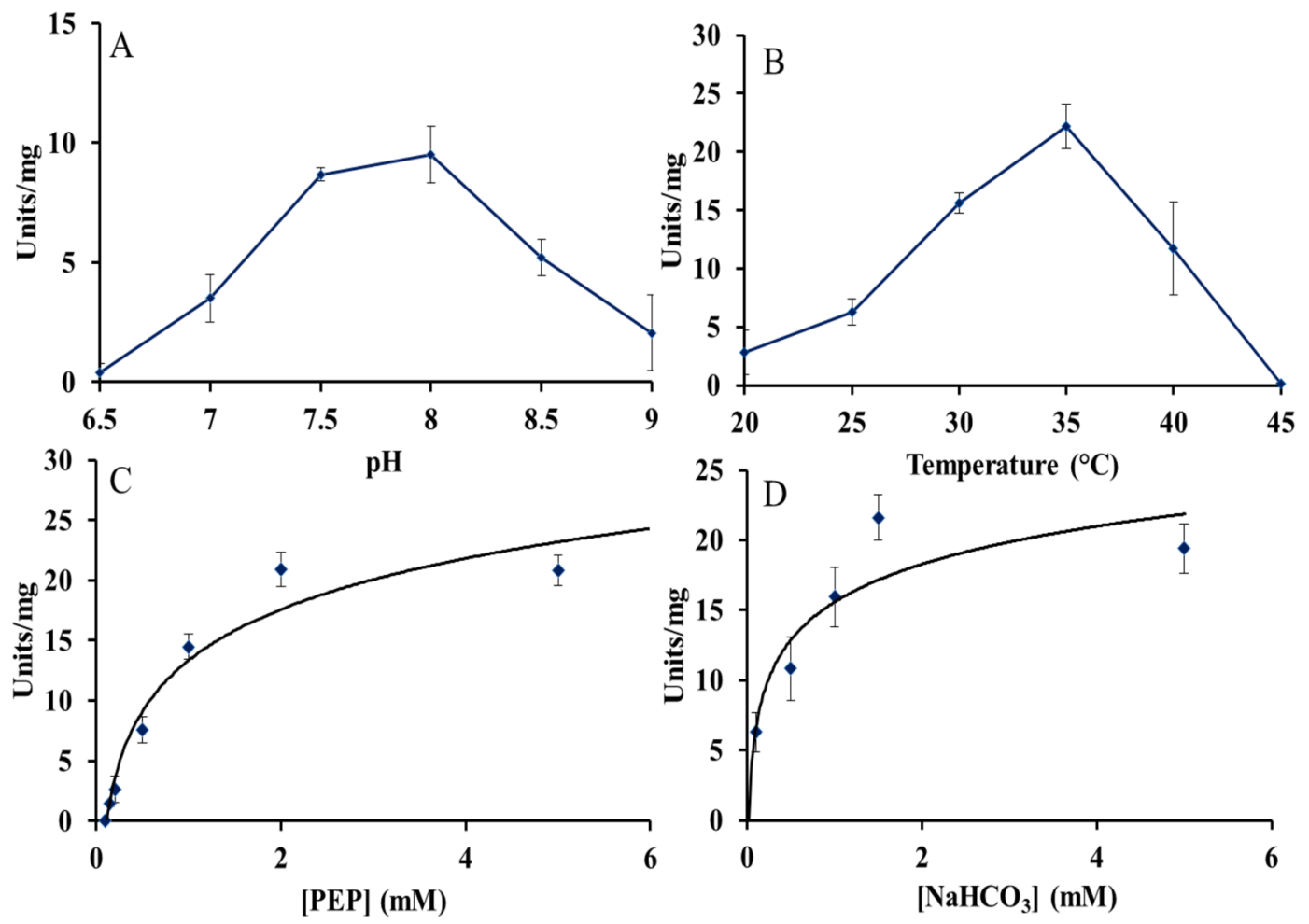

Figure 6. Specific activity of the T_PEPc PCC 7002- tetramer eluted with $25 \mathrm{mM} \mathrm{MgCl}_{2}$ (Supplementary Information Fig. S1-B, Table 1). (A) Specific activity at different $\mathrm{pH}\left(23^{\circ} \mathrm{C}\right)$. (B) Specific activity of at different

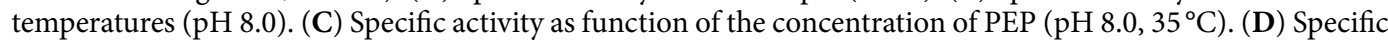
activity as function of the concentration of $\mathrm{NaHCO}_{3}\left(\mathrm{pH} 8.0,35^{\circ} \mathrm{C}\right)$. One unit is defined as $1 \mu \mathrm{mol}$ of $\mathrm{NAD}^{+}$ produced per minute.

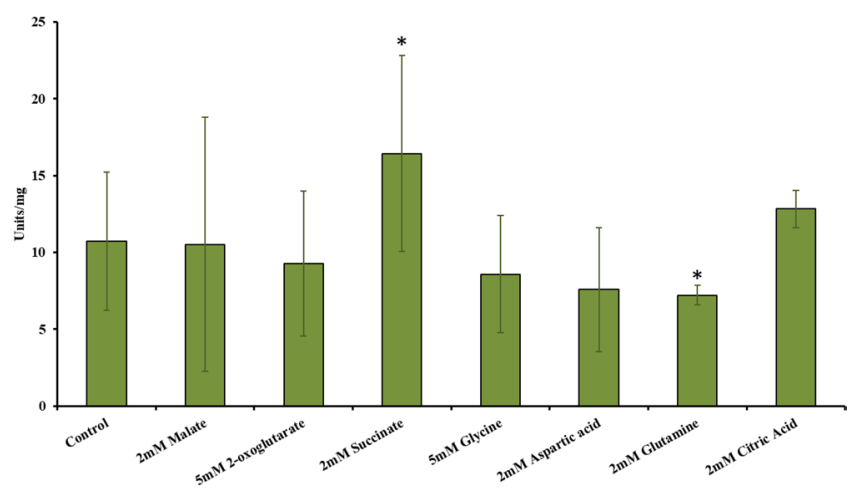

Figure 7. Specific activity of T_PEPc PCC 7002 in the presence of potential inhibitors or activators. The concentration of PEP and $\mathrm{NaHCO}_{3}$ was $1 \mathrm{mM}$. Asterisks asterisk indicates statistically significant difference (T-Test) compared to the control.

in Synechococcus) but do not show any inhibition by aspartate ( 9 , this study). Succinate has been reported to be an inhibitor of PEPc ${ }^{35,36}$, but in T_PEPc PCC 7002, it was instead shown to be an activator (Fig. 7). Even though it is not fully clarified, it seems that succinate is also an activator for PEPc from Synechocystis PCC $6803^{9}$. Surprisingly, T_PEPc PCC 7002 was inhibited by glutamine, although glutamine has been reported to be an activator of $\mathrm{PEPc}$ in the green alga Chlamydomonas reinhardtii, in one isoform of PEPc in S. minutum as well as the close related cyanobacterium $S$. volcanus $s^{3,5,7}$. In addition, it has been shown to induce pepc expression in maize leafs ${ }^{37}$. According to our understanding, glutamine may be an activator of PEPc since overexpression of PEPc should lead to an increased 2-oxoglutarate level. 2-oxoglutarate and glutamine react in order to form glutamate. However, the limitation of this study is that in the in vitro assay, the protein is isolated under optimal conditions and this may not be the condition in vivo. Thus, it may be that in vivo there are other factors affecting the carboxylase.

The scattering curves of the dimer and tetramer of PEPc PCC 7002 showed the best fit with the available structures of PEPc from E. coli (Supplementary Information, Table S1). These two prokaryotes have similar C3 


\begin{tabular}{|c|c|c|c|c|c|c|c|}
\hline Organism & $\mathbf{T}\left({ }^{\circ} \mathbf{C}\right)$ & pH & $\begin{array}{l}\text { V max } \\
\text { (units/mg) }\end{array}$ & $\begin{array}{l}\mathrm{Km}(\mathrm{PEP}) \\
\mathrm{mM}\end{array}$ & $\begin{array}{l}\mathrm{Km}\left(\mathrm{HCO}_{3}^{-}\right) \\
\mathrm{mM}\end{array}$ & Inhibitor/Activator & Reference \\
\hline $\begin{array}{l}\text { Anabaena PCC } 7120 \text { (filamentous } \\
\text { cyanobacterium) }\end{array}$ & 35 & 8 & 2.6 & 1.1 & 0.24 & $\mathrm{~A}, \mathrm{M}$ & 9 \\
\hline $\begin{array}{l}\text { Coccochloris peniocystis } \\
\text { (unicellular cyanobacterium) }\end{array}$ & 40 & 8 & 8.84 & 0.6 & 0.8 & $\begin{array}{l}\text { O, M lesser extent: C, } \\
\text { IC, O, ATP, D, ML, P/ } \\
\text { Pyr, 3PGA, NADPH }\end{array}$ & 8 \\
\hline $\begin{array}{l}\text { Synechococcus PCC } 7002 \\
\text { (unicellular cyanobacterium) } \\
\text { tetramer form }\end{array}$ & $35-35$ & $7.5-8$ & $14.43-20.74$ & $1.06-0.77$ & $0.97-0.24$ & n.t.- $\mathrm{Q} / \mathrm{S}$ & This study \\
\hline $\begin{array}{l}\text { Synechococcus vulcanus } \\
\text { (unicellular cyanobacterium) }\end{array}$ & $42 *(30)$ & $\begin{array}{l}9 \\
7.5\end{array}$ & $\begin{array}{l}25.3 \\
17.3\end{array}$ & $\begin{array}{l}0.53 \\
0.58\end{array}$ & \begin{tabular}{|l|l} 
nd \\
0.48
\end{tabular} & $\mathrm{D}$ & 7 \\
\hline $\begin{array}{l}\text { Synechocystis PCC } 6803 \\
\text { (unicellular cyanobacterium) }\end{array}$ & 30 & 7.3 & 1.74 & 0.34 & 0.8 & $\begin{array}{l}\text { Weak inhibition: } \mathrm{S}, \\
\text { M, F, C (pH 7.3) } \\
\text { Strong inhibition: } \mathrm{M} \text {, } \\
\mathrm{A}(\mathrm{pH}=9)\end{array}$ & 9 \\
\hline $\begin{array}{l}\text { Oceanimonas smirnovii (marine } \\
\text { bacterium) }\end{array}$ & 20 (RT) & 10 & 21.8 & 1.22 & 0.139 & & 30 \\
\hline $\begin{array}{l}\text { Chlamydomonas reinhardtii } \\
\text { (green alga) }\end{array}$ & 25 (n.s) & $\begin{array}{l}8.8 \\
8.1\end{array}$ & $\begin{array}{l}22 \\
18\end{array}$ & & & E,D,O,M/Q, DAP & 5 \\
\hline Selenastrum minutum (green alga) & $\begin{array}{l}25 \\
(\mathrm{n} . \mathrm{s})\end{array}$ & $\begin{array}{l}9 \\
9\end{array}$ & $\begin{array}{l}5.29 \\
5.71\end{array}$ & $\begin{array}{l}(\mathrm{S} 50) \\
2.23 \\
0.32\end{array}$ & & Q & 3 \\
\hline Zea mays (C4 plant) & 30 (n.s) & $\begin{array}{l}7.3 \\
8\end{array}$ & $\begin{array}{l}18.2 \\
23\end{array}$ & $\begin{array}{l}1.48 \\
0.59\end{array}$ & $\begin{array}{ll}0.12 \\
0.1\end{array}$ & $\mathrm{M}, \mathrm{D} / \mathrm{G} 6 \mathrm{P}$ & $7,9,23$ \\
\hline
\end{tabular}

Table 3. Characteristics of PEPc from different organisms. Abbreviations: ACoa- Acetyl-CoA, ATP- Adenosine Triphosphate, C-Citrate, D-Aspartate, DAP- Dihydroxyacetone phosphate, E-Glutamate, F- Fumarate, G6PGlucose-6-Phosphate, IC-Isocitrate, M-Malate, ML- Manolate, NADPH-Nicotinamide adenine dinucleotide phosphate, OAA-Oxaloacetate, O-2 oxoglutarate, P-Phosphate, Pyr- Pyruvate, Q-Glutamine, RT- Room temperature, S-succinate, 3PGA- 3-phosphoglyceraldehyde, (n.s)- temperature used for the activity assay but optimal temperature not specified, *Optimal temperature, in parentheses temperature used for the activity assay, n.t. no tested.

metabolism and the enzymes display $31 \%$ sequence identity, very slightly higher than the sequence identity of $30-31 \%$ between PEPc PCC 7002 and sequences from plants (Maize, Flaveria, Arabidopsis, Supplementary Information, Fig. S3). The analysis shows that all PEPc dimer structures, except the one from Clostridium where the protein is significantly smaller, are very similar in shape but that the inter subunit packing in the tetramer shows larger variation resulting in poorer fits to the SAXS data. Homology modelling of PEPc PCC 7002 based on available crystal structures (data not shown) did not generate a model with better fit to the SAXS profiles. This indicates that the main difference between the solution structure of the PEPc PCC 7002 tetramer and the crystal structures of $E$. coli PEPc may be in the inter-subunit packing. Future research will elucidate the structural details of the PEPc tetramer from cyanobacteria.

\section{Methods}

Construction of plasmid. To amplify pepc, gene encoding PEPc, from Synechococcus PCC 7002, genomic DNA was used as template together with Phusion High-Fidelity Hot Spot II DNA polymerase (Finnzymes) and primers for the gene with overhangs for restriction enzymes digestion (ForCTGAAGATCTAACCAAGTCATGCATCCCCC; Rev-GCATCTGCAGTCAACCCGTGTTCCGCAT). Obtained PCR product was purified (Gene JET Purification kit, Thermo Scientific) and digested by BglII and PstI fast restriction enzymes (Fermentas). The modified pET plasmid (pETBB) with a Strep-tag on the N-terminus and Bio brick assembly incorporated was digested by BamHI and PstI fast restriction enzymes. Both digested products (PCR and pETBB) were purified (DNA Clean \& Concentrator-5, Zymo Research) and ligated using the Quick Ligation Kit (New England Biolabs) at room temperature for $15 \mathrm{~min}$.

Transformation of $E$. coli BL21. $50 \mu \mathrm{L}$ of thawed ice cold competent cells of $E$. coli BL21 were mixed with $5 \mu \mathrm{L}$ of ligation mixture and incubated on ice for $30 \mathrm{~min}$. After that, a heat shock was performed for $1 \mathrm{~min}$ at $42^{\circ} \mathrm{C}$ before incubated on ice for 5 more min. $450 \mu \mathrm{L}$ of Luria Broth (LB) media (room temperature) was added in the tube, mixed and incubated at $37^{\circ} \mathrm{C}$ for 1 hour. Finally, the cells were centrifuged for $2 \mathrm{~min}$ at $13300 \mathrm{rpm}$ and $450 \mu \mathrm{L}$ of the supernatant was discarded. The cells were resuspended with the remaining supernatant and spread onto a LB agar place containing Kanamycin $(\mathrm{Km})\left(50 \mu \mathrm{g} \cdot \mathrm{mL}^{-1}\right)$ before placed overnight at $37^{\circ} \mathrm{C}$.

Overnight colonies were used to run a PCR in order to verify incorporation of the genetic construct. Dream Taq DNA polymerase protocol (Fermentas) was used together with detailed primers (Section 2.1). Positive colonies were grown using $\mathrm{LB}$ media containing $50 \mu \mathrm{g} \cdot \mathrm{mL}^{-1} \mathrm{Km}$ and incubated shaking, at $37^{\circ} \mathrm{C}$, overnight. Next day, the plasmids were extracted from the cells using JET Plasmid Miniprep Kit (Thermo Scientific) and sequenced (Eurofins) in order to confirm that the correct plasmid, and DNA sequence, was successfully transformed into the cells.

Cultivation of $E$. coli BL21. $10 \mathrm{ml}$ of overnight culture was inoculated in one litre of LB media supplemented with $5 \%$ of glucose and $\mathrm{Km}\left(50 \mu \mathrm{g} \cdot \mathrm{mL}^{-1}\right)$ (total $6 \mathrm{~L}$ ) and placed at $37^{\circ} \mathrm{C}$ under shaking conditions $\left(150 \mathrm{rpm}\right.$ ) until $\mathrm{OD}_{600}$ reached 0.4-0.6 (determined using UV-Visible Spectrophotometer 50 Bio). Then, the cells 
were cooled down to room temperature and induced with $0.1 \mathrm{mM}$ of IPTG. Afterwards, the cells were grown overnight at $25^{\circ} \mathrm{C}$ under constant shaking at $150 \mathrm{rpm}$. Next day, the cells were spun down at $5000 \mathrm{rpm}, 10 \mathrm{~min}$ at

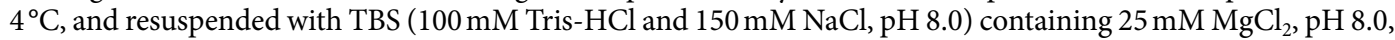
$1 \mathrm{mg}$ of RNAse, $1 \mathrm{mg}$ of DNAse and $0.6 \mathrm{mg} \cdot \mathrm{mL}^{-1}$ of inhibitor protease cocktail (G-Biosciences). The cells were then broken using a sonicator (Chemical Instruments AB, Model CV33) at 60\% amplification, with intervals of $15 \mathrm{sec}$ and $10 \mathrm{sec}$, and kept on ice. The mixture was centrifuged at $15000 \mathrm{rpm}$ for $1 \mathrm{~h} \mathrm{at} 4^{\circ} \mathrm{C}$. Obtained supernatant was transferred into Falcon tubes and frozen using liquid nitrogen.

Purification of PEPC PCC 7002. The supernatant was thawed on ice and then centrifuged at $15000 \mathrm{rpm}$ for $15 \mathrm{~min}$ at $4^{\circ} \mathrm{C}$, while the column (Strep Tag HP-GE Healthcare) was connected to an ÄKTA system at $4^{\circ} \mathrm{C}$ (GE-Healthcare). Then, the supernatant was filtered and loaded into the already equilibrated column (TBS + $25 \mathrm{mM} \mathrm{MgCl}_{2} \mathrm{pH} \mathrm{8.0)}$ at a flow rate of $2 \mathrm{~mL} \cdot \mathrm{min}^{-1}$. When the protein was loaded into the column, a washing step was performed using TBS containing $25 \mathrm{mM} \mathrm{MgCl}_{2}, \mathrm{pH} 8.0$ at $4{ }^{\circ} \mathrm{C}$. The attached Strep tag protein was eluted from the column using TBS containing $25 \mathrm{mM} \mathrm{MgCl}_{2} \mathrm{pH} 8.0$ and $2.5 \mathrm{mM}$ of desthiobiotin, concentrated using the Amicon Ultra-15 Centrifugal Filter Units MW $30 \mathrm{kDa}$, centrifuged at $5000 \mathrm{rpm}$ for $20 \mathrm{~min}$ at $4{ }^{\circ} \mathrm{C}$ and frozen using liquid nitrogen. The concentration of the protein was measured using a UV-Visible Spectrophotometer (50 Bio) and the Lambert $\mathrm{Law}^{38}$.

Size exclusion chromatography (SEC). The purified protein in TBS buffer containing $25 \mathrm{mM} \mathrm{MgCl} \mathrm{m}_{2}$ and $2.5 \mathrm{mM}$ desbiothin $\mathrm{pH}$ 8.0, was dialysed using the Slide-A-lyzer R Dialysis Cassette G2 (Thermo Scientific), to TBS buffer $\mathrm{pH} 8.0$, changing the buffer three times every two hours before left overnight at $4{ }^{\circ} \mathrm{C}$ under constant stirring. The dialyzed protein was then aliquoted and frozen with liquid nitrogen.

The column used for the Size Exclusion Chromatography (SEC, Hi L oad 16/60 Superdex 200, GE-Healthcare) was equilibrated with indicated buffer depending on experi ment (Table 1) at $4^{\circ} \mathrm{C} .500 \mu \mathrm{g}$ of purified protein was diluted (up to $570 \mu \mathrm{l}\left(0.87 \mathrm{mg} \cdot \mathrm{ml}^{-1}\right)$ with the same buffer as the column was equilibrated with before incubated at room temperature for $30 \mathrm{~min}$. The protein was then loaded in the column and eluted $\left(0.8 \mathrm{~mL} \cdot \mathrm{min}^{-1}\right)$ at $4^{\circ} \mathrm{C}$ with the same buffer as the column was previously equilibrated with before the protein was diluted and incubated. When the different sizes of proteins were eluted, they were concentrated using the Amicon Ultra-15 Centrifugal Filter Units MW $30 \mathrm{kDa}$ at $5000 \mathrm{rpm}$ for $20 \mathrm{~min}$ at $4{ }^{\circ} \mathrm{C}$ and frozen with liquid nitrogen. The concentration of the proteins were measured as detailed above. The ratios of the tetramer:dimer were calculated using the peak values obtained on the chromatogram.

SAXS. SAXS experiments were performed at beamline B21, Diamond Light Source, UK. $451 \mu$ g of dialysed PEPc PCC 7002 was incubated in either $400 \mu$ of TBS containing $25 \mathrm{mM} \mathrm{MgCl}_{2} \mathrm{pH} 8.0$ or TBS pH 8.0 for 30 min at room temperature. Then, the protein was concentrated by centrifugation using a $30 \mathrm{kDa}$ cut off concentrator (Amicon R Ultra). For SEC-SAXS, $50 \mu \mathrm{l}$ protein at $6.5 \mathrm{or} 0.87 \mathrm{mg} \cdot \mathrm{ml}^{-1}$ concentration was using an Agilent 1200 HPLC system loaded to a $4.6 \mathrm{ml}$ Shodex $\mathrm{KW}-403$ column run at $0.16 \mathrm{ml} \cdot \mathrm{min}^{-1}$ at room temperature in TBS or TBS with $25 \mathrm{mM} \mathrm{MgCl}_{2}$. For batch experiments, $25 \mu \mathrm{l}$ of $0.2,0.5,1,3$ or $4.29 \mathrm{mg} \cdot \mathrm{ml}^{-1}$ of protein were used in TBS $\mathrm{pH}$ 8.0. Data were recorded on an Eiger $4 \mathrm{M}$ detector with a fixed camera length of $4.014 \mathrm{~m}$ and $12.4 \mathrm{keV}$ energy, allowing an angular q range of $0.0038-0.42 \AA^{-1}$.

The SEC-SAXS data were buffer subtracted using buffer data frames in proximity to the peak using ScÅtter ${ }^{39}$ while batch data were buffer subtracted using Primus ${ }^{40}$. Data processing was performed using ScÂtter ${ }^{39}$ and Primus ${ }^{40}$ to obtain the radius of gyration $\left(\mathrm{R}_{\mathrm{g}}\right)$, the maximum particle dimension $\left(\mathrm{D}_{\max }\right)$, the excluded particle volume $(\mathrm{Vp})$ and the pair distribution function $(\mathrm{P}(\mathrm{r}))$. In addition, $\mathrm{Rg}$ and MW were derived using the SAXS MoW server $^{41}$. Theoretical scattering curves from $\mathrm{PDB}$ coordinates and their fits to the experimental scattering curves were calculated using the FOXS server ${ }^{42}$.

Sequence alignment. Structure-guided multiple sequence alignment of PEPc PCC 7002 with all PEPcs in the PDB was done using the Expresso server ${ }^{43}$.

In vitro PEPc activity measurements. The in vitro PEPc activity assays were performed as described by Codd and Stewart ${ }^{44}$ by adding $100 \mathrm{mM}$ Tris $\mathrm{pH} 8.0$ (except for the $\mathrm{pH}$ experiment where the $\mathrm{pH}$ varied from 6.5 to 9.0), $10 \mathrm{mM}$ of $\mathrm{MgCl}_{2}, 5 \mathrm{mM}$ of $\mathrm{NaHCO}_{3}, 0.15 \mathrm{mM}$ of NADH, $5 \mathrm{mM}$ of PEP and 8.25 units of malate dehydrogenase (MDH) from Heart Porcine (Merck). Then, the absorbance at $340 \mathrm{~nm}$ was measured (using a UV-Visible Spectrophotometer $50 \mathrm{Bio}$ ) and the reaction was activated by adding $0.348 \mu \mathrm{g}$ of purified and SEC obtained PEPc PCC 7002 of the TBS (containing $25 \mathrm{mM} \mathrm{MgCl}_{2}, \mathrm{pH}$ 8.0) experiment tetrameric fraction (Mg_25, Table 1, Supplementary Information Fig. S1-B). The mixtures were incubated for $10 \mathrm{~min}$ at $35^{\circ} \mathrm{C}$ (except for finding the optimal $\mathrm{pH}$ where $23^{\circ} \mathrm{C}$ was used) in a temperature incubator and the absorbances were measured again. The slope obtained by the measurements before and after the reaction was used to calculate the PEPc activity, expressed as units $\cdot \mathrm{mg}^{-1}$ of protein (where 1 unit represents $1 \mu \mathrm{mol}$ of $\mathrm{NAD}^{+}$formed $\cdot \mathrm{min}^{-1}$ ). When the reaction was performed with $10 \mathrm{mM} \mathrm{MgCl}_{2}, 5 \mathrm{mM} \mathrm{PEP}$ and no $\mathrm{NaHCO}_{3}{ }^{-}$the enzyme showed some activity. The value obtained in the later reaction was subtracted from all the values obtained during the kinetics except for the $\mathrm{pH}$ experiment. In order to calculate the $\mathrm{Km}$ and Vmax, Hanes-Woolf plot was used. The activation energy was calculated by using the Arrhenius equation plotting the Vmaxs from 0 to $35^{\circ} \mathrm{C}$.

When the potential inhibitors or activators were tested $(2 \mathrm{mM}$ malate, $5 \mathrm{mM}$ 2-oxoglutarate, $2 \mathrm{mM}$ succinic acid, $5 \mathrm{mM}$ glycine, $2 \mathrm{mM}$ aspartic acid, $2 \mathrm{mM}$ glutamine and $2 \mathrm{mM}$ citric acid), the procedure for the activity assay was the previously described but the amount of substrates were lowered to $1 \mathrm{mM} \mathrm{NaHCO}_{3}$ and $1 \mathrm{mM}$ PEP. In order to conclude if the substances tested were affecting the PEPc activity, T-Test were performed, with two tail distribution, two sample equal variance and $\mathrm{p}$ value 0.05 . 
Received: 18 September 2019; Accepted: 10 February 2020;

Published online: 27 February 2020

\section{References}

1. Durall, C. \& Lindblad, P. Mechanisms of carbon fixation and engineering for increased carbon fixation in cyanobacteria. Algal Res. 11, 263-270 (2015)

2. O'Leary, B., Park, J. \& Plaxton, W. C. The remarkable diversity of plant PEPC (phosphoenolpyruvate carboxylase): recent insights into the physiological functions and post-translational controls of non-photosynthetic PEPCs. Biochem. J. 436, 15-34 (2011).

3. Schuller, K. A., Plaxton, W. C. \& Turpin, D. H. Regulation of phosphoenolpyruvate carboxylase from the green alga Selenastrum minutum: properties associated with replenishment of tricarboxylic acid cycle intermediates during ammonium assimilation. Plant Physiol. 93, 1303-1311 (1990)

4. Rivoal, J., Dunford, R., Plaxton, W. C. \& Turpin, D. H. Purification and Properties of Four Phosphoenolpyruvate Carboxylase Isoforms from the Green Alga Selenastrum minutum: Evidence That Association of the 102-kDa Catalytic Subunit with Unrelated Polypeptides May Modify the Physical and Kinetic Properties of the Enzyme. Arch. Biochem. Biophys. 332, 47-57 (1996).

5. Rivoal, J., Plaxton, W. C. \& Turpin, D. H. Purification and characterization of high-and low-molecular-mass isoforms of phosphoenolpyruvate carboxylase from. Chlamydomonas reinhardtii. Biochem. J. 331, 201-29 (1998).

6. Rivoal, J., Trzos, S., Gage, D. A., Plaxton, W. C. \& Turpin, D. H. Two unrelated phosphoenolpyruvate carboxylase polypeptides physically interact in the high molecular mass isoforms of this enzyme in the unicellular green alga Selenastrum minutum. J. Biol Chem. 276, 12588-12597 (2001).

7. Chen, L. M., Omiya, T., Hata, S. \& Izui, K. Molecular characterization of a phosphoenolpyruvate carboxylase from a thermophilic cyanobacterium, Synechococcus vulcanus with unusual allosteric properties. Plant Cell. Physiol. 43, 159-169 (2002).

8. Owttrim, G. W. \& Colman, B. Purification and characterization of phosphoenolpyruvate carboxylase from a cyanobacterium. J. Bacteriol. 168, 207-212 (1986).

9. Takeya, M., Hirai, M. Y. \& Osanai, T. Allosteric inhibition of phosphoenolpyruvate carboxylases is determined by a single amino acid residue in cyanobacteria. Sci. Rep. 7, 41080 (2017).

10. Luinenburg, I. \& Coleman, J. R. A requirement for phosphoenolpyruvate carboxylase in the cyanobacterium Synechococcus PCC 7942. Arch. Microbiol. 154, 471-474 (1990).

11. Shylajanaciyar, M. et al. Analysis and elucidation of phosphoenolpyruvate carboxylase in cyanobacteria. Proteins 34, 73-81 (2015).

12. Andreo, C. S., Gonzalez, D. H. \& Iglesias, A. A. Higher plant phosphoenolpyruvate carboxylase. FEBS Letters 213, 1-8 (1987).

13. Ishijima, S. et al. Comparison of amino acid sequences between phosphoenolpyruvate carboxylases from Escherichia coli (allosteric) and Anacystis nidulans (non-allosteric): Identification of conserved and variable regions. Biochem. Biophys. Res. Commun. 133, 436-441 (1985)

14. Smith, A. A. \& Plazas, M. C. In silico characterization and homology modeling of cyanobacterial phosphoenolpyruvate carboxylase enzymes with computational tools and bioinformatics servers. Am. J. Biochem. Mol. Biol. 1, 319-336 (2011).

15. Coleman, J. R. \& Colman, B. Demonstration of C3 photosynthesis in a blue-green alga. Planta 149, 318-320 (1980).

16. Geiger, D. R. \& Servaites, J. C. Diurnal regulation of photosynthetic carbon metabolism in C3 plants. Annu. Rev. Plant. Biol. 45, 235-256 (1994)

17. Liang, F. \& Lindblad, P. Synechocystis PCC 6803 overexpressing RuBisCO grow faster with increased photosynthesis. Metab. Eng. Commun. 4, 29-36 (2017).

18. Eisenhut, M. et al. Metabolome phenotyping of inorganic carbon limitation in cells of the wild type and photorespiratory mutants of the cyanobacterium Synechocystis sp. strain PCC 6803. Plant Physiol. 148, 2109-2120 (2008).

19. Ehleringer, J. R. \& Cerling, T. E. C3 and C4 photosynthesis. Encyclop. Glob. Envir. Change 2, 186-190 (2002).

20. Wu, M. X. \& Wedding, R. T. Regulation of phosphoenolpyruvate carboxylase from Crassula by interconversion of oligomeric forms. Archiv. Biochem. Biophys. 240, 655-662 (1985).

21. Yu, J. et al. Synechococcus elongatus UTEX 2973, a fast growing cyanobacterial chassis for biosynthesis using light and $\mathrm{CO}_{2}$. Sci. Rep. 5, $8132(2015)$.

22. Willeford, K. O. \& Wedding, R. T. Oligomerization and regulation of higher plant phosphoenolpyruvate carboxylase. Plant Physiol. 99, 755-758 (1992).

23. Jiao, J. A. \& Chollet, R. Posttranslational regulation of phosphoenolpyruvate carboxylase in C4 and Crassulacean acid metabolism plants. Plant Physiol. 95, 981-985 (1991).

24. Kai, Y. et al. Three-dimensional structure of phosphoenolpyruvate carboxylase: a proposed mechanism for allosteric inhibition. Proc. Natl. Acad. Sci. 96, 823-828 (1999).

25. Matsumura, H. et al. Crystal structures of $\mathrm{C} 4$ form maize and quaternary complex of $E$. coli phosphoenolpyruvate carboxylases. Structure 10, 1721-1730 (2002).

26. Durall, C., Rukminasari, N. \& Lindblad, P. Enhanced growth at low light intensity in the cyanobacterium Synechocystis PCC 6803 by overexpressing phosphoenolpyruvate carboxylase. Algal Res. 16, 275-281 (2016).

27. Mukerji, S. K. Corn leaf phosphoenolpyruvate carboxylases: the effect of divalent cations on activity. Archiv. Biochem. Biophys. 182, 352-359 (1977).

28. Willeford, K. O., Wu, M. X., Meyer, C. R. \& Wedding, R. T. The role of oligomerization in regulation of maize phosphoenolpyruvate carboxylase activity: Influence of Mg-PEP and malate on the oligomeric equilibrium of PEP carboxylase. Biochem. Biophys. Res. Com. 168, 778-785 (1990).

29. Park, S., Lee, W., Kim, H., Pack, S. P. \& Lee, J. Characterization of Phosphoenolpyruvate Carboxylase from Oceanimonas smirnovii in Escherichia coli. Appl. Biochem. Biotechnol. 177, 217-25 (2015).

30. Owttrim, G. W. \& Colman, B. Phosphoenolpyruvate carboxylase mediated carbon flow in a cyanobacterium. Biochem. Cell Biol. 66 , 93-99 (1988).

31. Hanai, M. et al. The effects of dark incubation on cellular metabolism of the wild type cyanobacterium Synechocystis sp. PCC 6803 and a mutant lacking the transcriptional regulator cyAbrB2. Life 4, 770-787 (2014).

32. Price, G. D. Inorganic carbon transporters of the cyanobacterial $\mathrm{CO}_{2}$ concentrating mechanism. Photosynth. Res. 109, 47-57 (2011).

33. Coleman, J. R. \& Colman, B. Inorganic carbon accumulation and photosynthesis in a blue-green alga as a function of external pH. Plant Physiol. 67, 917-921 (1981).

34. Weigend, M. \& Hincha, D. K. Quaternary structure of phosphoenolpyruvate carboxylase from CAM-C4-and C3-plants-no evidence for diurnal changes in oligomeric state. J. Plant Physiol. 140, 653-660 (1992).

35. Ozaki, H. \& Shiior, I. Regulation of the TCA and glyoxylate cycles in Brevibacterium flavum: II. Regulation of phosphoenolpyruvate carboxylase and pyruvate kinase. J. Biochem. 6, 297-311 (1969).

36. Wong, K. F. \& Davies, D. D. Regulation of Phosphoenolpyruvate Carboxylase of Zea mays by Metabolites. Biochem J. 131, 451-458 (1973).

37. Sugiharto, B., Suzuki, I., Burnell, J. N. \& Sugiyama, T. Glutamine induces the N-dependent accumulation of mRNAs encoding phosphoenolpyruvate carboxylase and carbonic anhydrase in detached maize leaf tissue. Plant Physiol. 100, 2066-70 (1992).

38. Swinehart, D. F. The Beer-Lambert Law. J. Chem. Educ. 39, 333-335 (1962). 
39. Förster, S., Apostol, L. \& Bras, W. Scatter: software for the analysis of nano-and mesoscale small-angle scattering. J. Appl. Crystallogr. 43, 639-646 (2010).

40. Franke, D. et al. ATSAS 2.8: a comprehensive data analysis suite for small-angle scattering from macromolecular solutions. J. Appl. Crystallogr. 50, 1212-1225 (2017).

41. Piiadov, V. et al. SAXSMoW 2.0: Online calculator of the molecular weight of proteins in dilute solution from experimental SAXS data measured on a relative scale. Protein Sci. 28, 454-463 (2019).

42. Schneidman-Duhovny, D., Hammel, M., Tainer, J. A. \& Sali, A. Accurate SAXS profile computation and its assessment by contrast variation experiments. Biophys. J. 105, 962-974 (2013).

43. Armougom, F. et al. Expresso: automatic incorporation of structural information in multiple sequence alignments using 3D-Coffee. Nucleic Acids Res. 34, 604-608 (2006).

44. Codd, G. A. \& Stewart, W. D. P. Pathways of glycollate metabolism in the blue-green alga Anabaena Cylindrica. Archiv. Mikrobiol. 94, $11-28(1973)$

\section{Acknowledgements}

This work was supported by the NordForsk NCoE program "NordAqua" (project number 82845). We sincerely gratitude Brigitta Nemeth (Department of Chemistry-Ångström, Uppsala University) for all the shared knowledge in chromatography. The authors would like to thank Diamond Light Source for beamtime (proposal 15868) and Katsuaki Inoue for assistance during SAXS measurements. Open access funding provided by Uppsala University.

\section{Author contributions}

C.D. designed all the experiments, purified the enzyme, performed SEC, activity assays, SAXS and wrote the manuscript. S.K. analysed the SAXS data and wrote part of the manuscript. M.S. performed, supervised and analysed SAXS data, wrote part of the manuscript. P.L. supervised the work and revised the manuscript. All authors read and approved the final manuscript.

\section{Competing interests}

The authors declare no competing interests.

\section{Additional information}

Supplementary information is available for this paper at https://doi.org/10.1038/s41598-020-60249-2.

Correspondence and requests for materials should be addressed to P.L.

Reprints and permissions information is available at www.nature.com/reprints.

Publisher's note Springer Nature remains neutral with regard to jurisdictional claims in published maps and institutional affiliations.

(c) (i) Open Access This article is licensed under a Creative Commons Attribution 4.0 International License, which permits use, sharing, adaptation, distribution and reproduction in any medium or format, as long as you give appropriate credit to the original author(s) and the source, provide a link to the Creative Commons license, and indicate if changes were made. The images or other third party material in this article are included in the article's Creative Commons license, unless indicated otherwise in a credit line to the material. If material is not included in the article's Creative Commons license and your intended use is not permitted by statutory regulation or exceeds the permitted use, you will need to obtain permission directly from the copyright holder. To view a copy of this license, visit http://creativecommons.org/licenses/by/4.0/.

(C) The Author(s) 2020 